Трач Юлія Василівна, кандидат педагогічних наук, доцент, Київський національний університет культури імистецтв

\title{
ТЕНДЕНЦІї ТА ОСНОВНІ ПРОЯВИ ВІРТУАЛІЗАЦІї СУЧАСНОЇ КУЛЬТУРИ
}

У статті з точки зору культурології розкрито прояви віртуалізації сучасної культури, зокрема зазначено, щзо вся світова культура певним чином пов'язана з твореними людиною віртуальними світами, на основі яких описується теоретикопізнавальний аспект людської діяльності. Звернено увагу, щзо віртуальну реальність можна розглядати як нову техніку репрезентації, яка в найближчому майбутньому багато в чому визначатиме естетичний досвід людства. Розглянуто питання комп'ютерних сочіальних мереж як одного з найбільи поширених та істотних культурних артефактів сучасності. Наголошено на необхідності послідовного $і$ систематичного культурологічного аналізу феномена віртуальності.

Ключові слова: віртуальне, віртуальна реальність, віртуалізачія, культура, комп 'ютерні сочіальні мережі.

В статье с точки зрения культурологии раскрыто проявления виртуализачии современной культуры, в частности указано, что вся мировая культура определенным образом связана с творимыми человеком виртуальными мирами, на основе которых описывается теоретико-познавательный аспект человеческой деятельности. Обращено внимание, что виртуальную реальность можно рассматривать как новую технику репрезентации, которая в ближайшем будущем во многом будет определять эстетический опьт человечества. Рассмотрень вопросы компьютерных социальных сетей как одного из наиболее распространенных и существенных культурных артефактов современности. Отмечена необходимость последовательного и систематического культурологического анализа феномена виртуальности.

Ключевые слова: виртуальное, виртуальная реальность, виртуализация, культура, компьютерные сочииальные сети.

This article from the perspective of cultural studies disclosed virtualization manifestations of contemporary culture, in particular, pointed out that the entire global culture in a certain way connected with man-soluble virtual worlds, on the basis of which is described epistemological aspect of human activity. The attention that virtual reality can be seen as a new representation technique that in the near future will largely determine the aesthetic experience of mankind. The problems of computer social networks as one of the most common and important cultural artifacts of our time. There was a need for a consistent and systematic cultural analysis of the phenomenon of virtuality. Key words: virtual, virtual reality, virtualization, culture, social computer network. 
Суперечливість і багатоплановість різних соціальних і технічних процесів межі двох тисячоліть актуалізували теоретичне осмислення спрямованості змін, що відбуваються в сучасній цивілізації. Ці зміни, торкаючись країн, регіонів, всієї людської цивілізації, стимулюють інтерес дослідників до масштабного аналізу того, що відбувається. Зокрема, «вибух» інтересу до феномена віртуальності пов'язують із створенням сучасних комп'ютерних технологій, однак вони лише привернули до нього увагу. Сьогодні в результаті колективної діяльності учених, розробників, інженерів і програмістів створено цілий комп'ютерний віртуальний світ, «кіберпростір», який кардинально змінив життя людства і залучив у свою динаміку мільярди людей.

Охоплюючи значний соціокультурний простір у сучасному світі, феномен віртуалізації став невід'ємним компонентом усіх сфер соціальної реальності і все частіше розглядається в якості специфічної характеристики постмодерністського світовідчуття. Як справедливо зазначає М. С. Уваров: «Показовий факт віртуалізації сьогоднішнього суспільства, в якому симулятивна діяльність набуває таких масштабів, що дає підстави говорити про втрату стійкості соціальних структур і про відчуття примарності і нестабільності соціального буття в ситуації постмодерну. < ..> Причому віртуальні інформаційні технології-це лише одне з можливих втілень симуляції, прояви якої можна знайти і в сфері міжособистісних і сексуальних відносин, у мистецтві, в політиці тощо» [16, с. 70].

Як і будь-яке інтенсивно пізнаване явище, віртуальність, або віртуальна реальність, розглядається і вивчається з дуже різних, іноді протилежних позицій, тому це поняття вже стало багатозначним.

У сучасній культурологічній думці домінуючими є уявлення про віртуальне як про створений людською діяльністю штучний феномен, який має специфічні властивості. Першими «культурний потенціал» віртуальних реальностей оцінили їі розробники - Дж. Ланьє, М. Крюгер, У. Брік. На початку 1990-х рр. віртуальною реальністю зацікавилися філософи, соціологи, психологи, мистецтвознавці, культурологи. При цьому саме міждисциплінарний характер дискурсу i поліфункціональний характер явища ВР зробили його особливо привабливим для культурологічного аналізу.

Грунтовними культурологічними працями з питань ВР, які дають змогу отримати уявлення про даний феномен, є дослідження М. Кагана, Л. Мосолової, А. Карміна, С. Іконнікової та ін. [8; 6]. Питання ВР у контексті проблем культури, духовності, моральності розглянуті в працях Р. Яновського [18]; питання кіберкультури - у працях Т. Лірі [12]; питання віртуальної реальності в сучасному мистецтві - О. Астаф’євої та ін. [2]; питання трансформацій в естетиці та культурі-Н. Маньковської, Ю. Легенького та ін.

Проблеми комп'ютерної ВР вивчаються й у ряді філософських і природничонаукових досліджень. Зокрема, С. Капіца та ін. [9] розглядали у своїх працях технічні та програмні засоби систем віртуальної реальності; В. Шапіро - методологічні проблеми розробки систем комп'ютерної віртуальної реальності [17]; В. Стьопін - людиномашинні системи, складні інформаційні комплекси і системи штучного інтелекту [14]; В. Іноземцев, М. Кастельс, Г. Рейнгольд - проблеми віртуальної реальності в контексті становлення інформаційного суспільства [7; 10]. 
Незважаючи на певні здобутки у вивченні проблеми комп’ютерної віртуальної реальності, донині бракує цілісного, узагальнюючого дослідження віртуальної реальності з культурологічної точки зору. Зокрема, потребують вивчення її прояви в сучасній культурі. Йдеться не лише про трансформацію видів мистецтва, а й виникнення нових, появу специфічних субкультур, застосування технологій ВР у різних сферах культури, i, врешті решт, появу віртуальної культури. Аналіз цих проявів й становить мету статті.

Віртуальна реальність (ВР) - технологія, що зародилася в 60-х роках XX ст. на перетині досліджень у сфері тривимірної комп'ютерної графіки і людино-машинного інтерфейсу. Сплеск суспільного інтересу до ВР на початок 1990-х рр., час перших успіхів технології. ХХ ст. не лише повернуло до життя забуте поняття «віртуальний», але зробило його словом, яке у зв’язку з комп'ютерами, телебаченням та Інтернетом. 3 допомогою цього слова намагаються охопити «дух часу» i, відповідно, визначити роль людини в історії. «Віртуальний» належить до ключових слів сучасності, на відміну від штампів і розмитих метафор, як, наприклад, «комп’ютерна епоха» чи «науковотехнічна революція». На початок XXI ст. ВР досягла певного рівня зрілості, на що вказують масовість і технологічність їі застосувань. Сфери застосування ВР надзвичайно різноманітні: це тренажерні системи, промислове і архітектурне проектування, візуалізація наукових даних, освіта, медицина, мистецтво, розваги. Наймасовіша сфера застосування ВР - це, безумовно, комп'ютерні ігри.

Метою розробників ВР було створення максимально природного інтерфейсу, усунення «зазору» між людиною і комп’ютером. Технологія віртуальної реальності передбачає симуляцію чуттєвих даних, які формують «ніби реальний» досвід. При всій різноманітності комп'ютерних систем віртуальної реальності їх об'єднує вироблюваний ефект - ефект занурення, який полягає в тому, що користувач перестає відчувати себе зовнішнім спостерігачем і включається у віртуальне оточення, починає сприймати його «як справжнє» або «майже як справжнє».

ВР - не лише «чергова комп’ютерна технологія», вона належить до тих знакових досягнень науки і техніки, з появою яких пов'язують зміни в багатьох сферах людської діяльності, в масовій свідомості. Дослідження ВР проблем буття, вивченнярозуму і відчуттів людини, а також сучасної культури. ВР примушує по-новому підійти до проблеми співвідношення символу і образу, конкретно-чуттєвого і абстрактнорозсудливого пізнання, переосмислити роль уяви і фантазії. Віртуальну реальність можна розглядати як нову техніку репрезентації, яка в найближчому майбутньому багато в чому визначатиме естетичний досвід людства. ВР стає овищем спілкування і соціалізації сучасників. Вже сьогодні ВР впливає на повсякденний досвід і, відповідно, поведінку в реальному світі.

Кожна технологія - це втілення ідеології суспільства або, швидше, - ідеологічні інвестиції суспільства у власне найближче майбутнє. Тому ВР можна розглядати не лише як чинник масштабних змін, а й як вираження сучасних культурних тенденцій. Таким чином ВР стає метафорою при розгляді актуального стану культури і його теоретичному осмисленні, метафорою, яка не стільки прикрашає чи ілюструє думку, скільки слугує їй інструментом. 
ВР - це технологія конструювання штучних світів, які можуть посперечатися по достовірності світом реальним. Віртуальна реальність пропонує переосмислити одвічні питання: що таке реальність? які методи їі пізнання? як світ довкола людей співвідноситься з їхніми відчуттями й уявленнями? де межа між культурою і натурою, штучним і природним?

Комп’ютерна реалізація віртуальної реальності занурює людину в штучний світ. Щоб досягти цілковитої реальності зовсім не потрібно моделювати навколишній світ до найдрібніших моментів. Обов'язкова присутність лише двох моментів. Перший момент полягає в тому, що крім простого передання зорової інформації, такі програми одночасно впливають ще на деякі органи чуття, включаючи слух і навіть дотик. Другий полягає в тому, що в системах користувач може доторкнутися рукою до об'єкту, який лише в пам'яті комп'ютера, надягнувши обладнану датчиками рукавичку. Віртуальна реальність в комп'ютерній науці - це те, що дозволяє переміщатися у тривимірному світі з шістьма рівнями свободи і дозволяє оглядати його в реальному часі. Людина потребує фіктивного подвоєння світу.

Технологічно продукована «віртуальна реальність» на сьогодні втрачає статус техногенних явищ, що належать винятково до сфери техніки і стає у певному сенсіметафорою, що дозволяє хоч би в загальних рисах визначити контури тих реалій культурологічного, антропологічного і філософського характеру, з якими людство стикається на межі століть. Йдеться про пізнавальну ситуацію, що досить радикально відрізняється від традиційної.

Так звана «соціальна віртуальна реальність», «нульовий» простір, «паралельний» світ, нове «місце існування», «кіберпростір»-це не лише взаємозв’язані $з$ допомогою комунікаційного і програм комп'ютери, а, люди, що взаємодіють у цьому середовищі 3 продуктами своєї активності. Людська активність в середовищі Інтернет підпорядкована задоволенню трьох основних потреб: комунікативної («все населення планети - серед Ваших партнерів»), пізнавальної («всі знання світу-біля Ваших ніг») і ігрової («наше життя - гра»). Соціальний віртуальний простір Інтернет як ноосферне явище - не лише віддзеркалення наявних політичних, економічних чи яких-небудь ще реальностей, а й у певному значенні автономна суть, що активно впливає на предметний світ. Розвиток електронних комп'ютерних мереж стає тим чинником, який можна вважати за формоутворювальний для культури віртуальної реальності.

Соціальна віртуальна реальність і можливості творити, що незвичайно розширилися - принципово привабливі риси середовища Інтернет сьогодні. Соціальна віртуальна реальність - це особлива субкультура зі своїми ідеалами, принципами, певною мовою і стилем спілкування. Багато що зі створеного, образно кажучи, «на клавішах», має естетичну цінність, і шедеври «комп’ютерних майстрів» примушують задуматися про виникнення нового виду мистецтва зі своєю естетикою.

Таким чином сучасні комунікаційні технології стимулюють виникнення нового виду мистецтва і значно змінюють класичну парадигму творчості, побудовану на опозиції автора і публіки. «Інтерактивне телекомунікаційне мистецтво, в якому перетинаються взаємно стимульовані індивідуальні креативні потоки, виразно демонструє соціально-комунікативну природу творчості, що не завжди виявляється явно і відкрито в інших сферах творчої діяльності» [4]. 
Серед основних напрямів віртуалізації суспільства виокремлюють віртуалізацію економіки, яка виявляється у створенні мережевої економіки, електронних ринків продукції, у розвитку міжнародної мережі електронних магазинів, ринку цінних паперів; віртуалізацію політики, пов'язану із створенням віртуальних політтехнологій; віртуалізацію культури, пов' язану з PR-технологіями, створенням електронної преси та книг; віртуалізацію науки; та віртуалізацію системи освіти. Крім того, широко досліджуються соціально-особистісні аспекти віртуальної реальності, такі, як втеча від реальності, критичне ставлення до традиційного, отримання задоволень, зв'язок віртуальності із сьогоденням, минулим і майбутнім. 3'являються та аналізуються нові поняття, що відповідають новим явищам: «віртуальний продукт», «віртуальна інновація», «віртуальна організація», «віртуальні гроші», «віртуальні потреби», «віртуальна культура».

Дослідження віртуальної реальності постулює, що вся світова культура певним чином пов' язана з твореними людиною віртуальними світами, на основі яких описується теоретико-пізнавальний аспект людської діяльності. Віртуальна реальність, створена творцем-художником, творцем-музикантом, творцем-поетом, $є$ інтерактивною. Вона дає глядачеві, слухачеві, читачеві підключатися до неї, занурюватися в неї, існувати в ній. Віртуальні світи дозволяють досліджувати процеси вільного становлення і виникнення принципово нових структур, характерних для будь-якої творчості, без яких будь-який суб'єкт культури не може обійтися.

Електронну, тобто комп'ютерну, віртуальну реальність за архітектурою можна поділити на автономну і мережеву, в результаті взаємодії з якими людина формує віртуальну культуру. У формуванні уявлень про віртуальну культуру в історії наукової думки можна виокремити: ранні дослідження описового характеру, серед яких вирізнялися «технологічна утопія» або «технологічна антиутопія»; дослідження, де головна увага зосереджена на появі феномена віртуальних спільнот; дослідження, де увага зосереджена на аналізі соціальних, культурних та економічних взаємодій, що відбуваються в мережі Інтернет, включаючи соціальне конструювання реальності, створення етичних кодексів поведінки в Інтернеті тощо.

Віртуальні форми діалогічних відносин породжують нові форми діалогу культур, які умовно позначають як віртуальний діалог, реально-віртуальний діалог, віртуальнореальний діалог. Перший відбувається у свідомості читача-користувача, коли віртуальне середовище виступає сховищем і засобом передання інформації, подібно до паперової енциклопедії чи документального фільму, але відрізняється можливістю нелінійного прочитання. Другий відбувається, коли користувач за комп’ютером «читає» твір розробників програм. Тут відбувається реальний діалог з віртуальним об'єктом, в який вкладено природний інтелект автора. Третій виражається у вигляді діалогів з реальними співрозмовниками, в результаті яких осягаються образи іншої культури.

У цьому контексті варто звернути увагу на один з найбільш поширених та істотних культурних артефактів сучасності - комп’ютерні соціальні мережі, які впливають не лише на окремі сторони способу життя людей, а й торкаються фундаментальних основ самого життя людини, формують віртуальний модус буття, породжують нового суб' єкта культури. Розглядати комп'ютерну соціальну мережу лише як похідну розвитку 
інформаційно-комунікаційних технологій неправомірно. Такі сайти, безперечно, $\epsilon$ супровідним явищем Інтернету, черговим технічним досягненням людства, проте вони виникли не лише в результаті технічного прогресу, а й завдяки світовідчуттям і світогляду сучасної людини.

Будучи об'єктивним та універсальним засобом, який знаходить застосування в багатьох сферах життєдіяльності людини, комп’ютерні соціальні мережі перетворилися на надгалузеву технологію, задіяну майже у всіх сферах культури. Однак ці сфери не можна розглядати як щось, що належить виключно світу техніки, вони настільки глибоко проникли в життя людей, вплелися в саму тканинуії повсякденності, що вичленувати їх iз загального світоглядного та культурологічного контексту вже неможливо. Тому сьогодні важливо визначити соціально-культурну роль феномена комп'ютерної соціальної мережі як провісника майбутнього техногенної цивілізації, його вплив на зміну сутності і буття людини, вплив на культуру та виникнення нових субкультур.

Центральна роль, яку відіграють комп'ютерні соціальні мережі в процесі віртуалізації сучасної культури, інакше ставить питання причин і підстав величезної популярності подібних сайтів, глибокої залученості великої кількості користувачів різного віку і професій в нову форму міжсуб' єктної взаємодії, тривалого перебування в електронному просторі. При цьому можливості сайтів соціальних мереж повинні оцінюватися в якості важливого, але другорядного фактора масштабної експансії даного феномена в життєвий простір індивіда.

Крім того, інтенсивний процес інформатизації та автоматизації всіх сфер людської діяльності (електронні гроші, мобільні пристрої, портативні комп'ютери, Інтернетмагазини, відеоконференції, електронна форма послуг тощо) звужує поле прийняття самостійних рішень, змушуючи людини адаптуватися до змін шляхом активного освоєння інновацій. Подібно до того, як в XIX ст. після першої науково-технічної революції люди, які не вміють читати, виявилися на узбіччі громадського життя, так i сьогодні, у другому десятилітті XXI ст., індивіди, які не володіють елементарними навичками роботи 3 мобільним телефоном, комп'ютером, не мають доступу до Інтернету і не зареєстровані в соціальній мережі, ризикують опинитися на периферії культурно-історичного процесу. Оволодіти інформаційними технологіями і грамотно використовувати їх стало неминучою вимогою часу, життєво важливою метою людини, якщо вона не хоче перебувати в ролі аутсайдера, оскільки технологічні інновації кардинально перетворюють не лише способи взаємодії людей, організацію праці, роль системи освіти, економічну і політичну сфери, а й безпосередньо впливають на саму людину, середовище ії проживання, механізми соціалізації. Таким чином, сучасна людина певною мірою позбавлена вільного вибору в питанні використання/ігнорування тієї чи іншої технології, їй доводиться жити у вузьких межах «технотронного суспільства» (3. Бжезинський) і робити те, що задано і наказано, в тому числі бути користувачем соціальної мережі. Однак тут важливо усвідомити, що існує загроза інформаційної нерівності, коли частина людей з різних причин виявиться поза масовою технологією (технічна неграмотність, технофобія, елементарна відсутність технології).

Узагальнюючи вищевикладене, варто відзначити, що в даний час ми є свідками формування нового способу соціокультурного буття індивіда, що вкладається в межі 
масштабного процесу віртуалізації сучасної культури. Виходячи з того, що зміст процесу віртуалізації культури не зводиться виключно до маніпуляцій в межах новітніх IT-розробок або медіа-середовища як обов'язкових компонентів, то віртуалізацію таких сфер соціальної реальності як економіка, політика, мистецтво, наука і віртуалізацію приватного буття індивіда, реалізовану з допомогою соціальної мережі, слід розуміти як взаємопов' язані явища одного порядку, що істотно змінюють соціальну та духовну природу людини. Основна відмінність полягає в тому, що в першому випадку превалює соціальна симуляція, а в другому йдеться про панування технологічного механізму підміни автентичних зразків.

Аналіз феномена віртуальної реальності і безлічі праць, присвячених його дослідженню, свідчить про відсутність ясності і єдності навіть у визначенні віртуальності. Крім того, праці, присвячені послідовному культурологічному аналізу віртуальності, пошукуїі істотних властивостей і сенсу, що досліджують віртуальність як складний, багаторівневий феномен, у даний час практично відсутні. Це зумовлює необхідність з'ясування того, що ж насправді може вважатися віртуальним, які є типи віртуальних об' єктів і яким чином їх класифікувати.

Множинність уявлень про феномен віртуальності, фрагментарність його дослідження, відсутність системності та цілісності у культурологічному осмисленні феномена віртуальності актуалізує необхідність його послідовного і систематичного культурологічного аналізу.

\section{Лimepamypa}

1. Акчурин И. А. Виртуальные миры и человеческое познание / И. А. Акчурин // Общетеоретические и логические проблемь виртуальных миров. - Москва, 2000. - С. 9-29. 2. Астафьева О. Н. Компьютерная виртуальная реальность как игровая форма культуры/ О. Н. Астафьева // ПОИСК. Вып. IV. Актуальные проблемы духовности, культуры, искусства. - Москва : РИЦ ИСПИ РАН, 2003. - С. 103-117. 3. Баксанский О. Е. Виртуальная реальность и виртуализация реальности / О. Е. Баксанский // Концепџии виртуальных миров и научное познание. - Санкт-Петербург : РХГИ, 2000. - С. 292-305. 4. Дубина И. Н. Современное телекоммуникационное искусство: становление новой парадигмы творчества / И. Н. Дубина [Электронный ресурс]. - Режим доступа : www.philosophy.ru/ library/dubina/index.html. 5. Иванов Д. В. Феномен компьютеризации как социальная проблема / Д. В. Иванов [Электронный ресурс]. - Режим доступа : www.soc.pu.ru.8101/ publckations/pts/divanov.html. 6. Иконникова C. Н. Виртуальная реальность как новая технология и способ постижения действительности / С. Н. Иконникова // Виртуальная реальность. Наука. Культура. - Санкт-Петербург, 1996. - С. 5-8. 7. Иноземиев В. Л. Современное постиндустриальное общество: природа, противоречия, перспективы / В. Л. Иноземцев. - Москва, 2000. - 304 с. 8. Каган М. С. Философия культуры / М. С. Каган. Санкт-Петербург : Петрополис, 1996.-416с.9. Капица С. П. Очевидное невероятное. Программа, посвященная проблеме компьютерных виртуальных технологий / С. П. Капий. - Москва : ОРТ, 1996. 10. Кастельс М. Становление общества сетевых структур / М. Кастельс // Новая постиндустриальная волна на Западе: Антология. Москва : Acadeтіа, 1999. - 560 c. 11. Кузнецов М. М. Виртуальная реальность-техногенный артефакт или сетевой феномен / М. М. Кузнецов [Электронный ресурс]. - Режим доступа : www.synergetic.ru/philisiphy/ - Загол. с экрана. 12. Лири Т. Семь языков бога. [Часть 
четвертая. Хаос и киберкультура ] / Т. Лири [Электронный ресурс]. - Режим доступа : http://www.psyoffice.ru/8/psichology/book_o177_page_29.html 13. Малясов Г. В. Виртуальная реальность: в поисках антропной идентичности / Г. В. Малясов // Материаль межвуз. конф. - Казань, 2000. - С. 35-38. 14. Степин В. С. Философия науки и техники : учеб. пос. I B. С. Степин, Горохов В.Г., Розов М.А. - Москва : Изд-во: Гардарики, 1999. - 400 с. 15. Таратута Е. Е. Философия виртуальной реальности / Е. Е. Таратута. - СПб., 2007. 147 с. 16. Уваров М. С. Третья природа: размышления о культуре и иивилизации / М. С. Уваров. - Санкт-Петербург : Изд-во С.-Петерб. ун-та, 2012. - 252 с. 17. Шапиро Д. И. Виртуальная реальность и проблемы нейрокомпьютинга / Д. И. Шапиро. - Москва : Изд-во «РФК-ИмиджЛаб», 2008. - 454 с. 18. Яновский Р. Г. О виртуальной реальности / Р. Г. Яновский // Виртуальные реальности: Труды лаборатории виртуалистики. Bып. 4. / под ред. Р. Г. Яновского, Н. А. Носова. - Москва. : Ин-т человека РАН, 1998. - С. 134-138. 